\title{
UNUSUAL DEBRIS-COVERED ICE CONES FROM UMNAK ISLAND*
}

\author{
By RAYMond F. MCALlister
}

\begin{abstract}
(Marine Research Geologist, Department of Oceanography, Agricultural and Mechanical College of Texas, College Station, Texas)
\end{abstract}

THE ice cones described below were observed during the summer of 1948 in the course of an expedition undertaken as part of the Beach Reconnaisance program of the United States Navy, Office of Naval Research, Amphibious Branch, at Cornell University, Ithaca, New York, while the author was a member of that University. Although they were not studied in as much detail as desired, they seemed unusual enough to warrant this brief report.

Umnak, the third largest of the Aleutian Islands, holds the huge caldera of Mount Okmok, a volcano which suffered a catastrophic eruption and collapse in Post-Pleistocene time1. Within this caldera, $12 \mathrm{~km}$. across, there are nine volcanic cones, of which Cone $A$ is the most active, having undergone a vigorous eruption in 1945 and some minor activity since. Between Cone A and the caldera wall is an active glacier about $8 \mathrm{~km}$. long, and arcuate in shape, stagnant at its eastern extremity. The area discussed in this paper is located approximately $1.6 \mathrm{~km}$. from the north-east end of the glacier and about $\mathrm{x} \mathrm{km}$. from the crater of Cone A. An almost continuous blanket of low clouds covers the caldera throughout the year, and precipitation occurs almost every day.

Under a uniform blanket of ash perhaps 10 to $13 \mathrm{~cm}$. deep the glacier was covered with névé (or ice) cones as shown in Figs. I and 2 (p. 633). The ash was scraped from about twenty of these cones and each one had at its summit a small pit or crater giving it the appearance of a small ice "volcano." The cones varied in basal diameter from 50 to $125 \mathrm{~cm}$. and in height up to a maximum of $62 \mathrm{~cm}$. The craters studied ranged from 2 to $16 \mathrm{~cm}$. across the top, and from $1 \cdot 3$ to more than $77 \mathrm{~cm}$. in depth.

Several of the shallower craters were floored with ice and ash solidly frozen together, in one case the frozen mixture reaching within $1 \mathrm{~cm}$. of the crest, and overlain with loose moist ash. Others contained loose ash to the full depth of the crater. All the craters were round or nearly so, and at least the larger ones tapered slightly inward toward the bottom. They were situated at the summit of the neve cones, the sides of which slope at 25 to 35 degrees. The cones did not appear to be aligned in any direction. No volcanic ejecta, other than the ash blanket, were observed in the vicinity.

These cratered cones represent peculiar surface features which apparently have not been previously reported. Possibly they are relict features, predating the ash fall, although no evidence for this was seen. Lewis ${ }^{2}$, Swithinbank ${ }^{3}$ and Wilson ${ }^{4}$ propose that an uneven debris cover might have caused such a hummocky ice surface. These cones, however, seem to have developed under a uniform insulating ash cover, thick enough to have preserved until 1948 the snow beneath the ash fall of 1945, as exposed elsewhere. The cracking of the ash cover over them suggests that the cones postdate the ash fall.

No reference to craters of the sort described here was found in the literature. Swithinbank and Lewis both depict a cleft extending across the crest of a cone, effectively breaching it and wholly unlike the central crater shown in the figures in this paper (see also Lewis ${ }^{2}$, Fig. 6, p. 22). The debris-filled cleft described by Swithinbank and by Lewis is the remnant of a crevasse filling, and there is no evidence of crevassing on the Okmok glacier near the cones, nor are the cones aligned in any way suggestive of a crevasse pattern.

\footnotetext{
* Contribution from the Department of Oceanography of the Agricultural and Mechanical College of Texas, Oceanography and Meteorology Series, No. \#55.
} 
Colleagues have suggested that the craters represent points of rapid ablation where, at the bottom of tension cracks in the ash at the summit of the cones, insolation can reach the névé without encountering a $10 \mathrm{~cm}$. thick insulating blanket. However, such a proposal fails to explain how more than $77 \mathrm{~cm}$. of ash came to be in one crater measured and how, if infall of ash were responsible for the fill, the overlying ash still maintained its normal 10 to $13 \mathrm{~cm}$. thickness. It is doubtful that wind blown ash could have filled the craters since no evidence of wind shifting of the ash was noted, and the depressions between hummocks were not drifted full. The moist ash would not have been easily blown about.

An effective explanation of the cratered debris-covered ice cones must await further observations, and the author would appreciate information from others who have observed similar phenomena.

An interesting sidelight is provided by the preservation of the snow of $1944-45$ as néré under the ash while subsequent snowfalls melted completely.

MS. received Io March, 1955

\section{R E F E R E N C E S}

I. Byers, F. M., Jr., Hopkins, D. M., Wier, K. L., and Fischer, B. Volcano investigations on Umnak Island, r 946 . Alaskian Volcano Investigations, Report No. 2, Part 3, 1947, p. 19-53.

2. Lewis, W. V. Dirt cones on the northern margins of Vatnajökull. Fournal of Geomorphology, Vol. 3, No. I, 1940, p. $16-26$.

3. Swithinbank, C. The origin of dirt cones on glaciers. Journal of Glaciology, Vol. I, No. 8, 1950, p. $461-65$.

4. Wilson, $J$. W. The initiation of dirt cones on snow. Journal of Glaciology, Vol. 2, No. 14, 1953, p. $281-87$.

\section{COMMENTS ON MR. MCALLISTER'S PAPER \\ $B y$ W. V. LewIS \\ (Department of Geography, Cambridge University)}

THE interesting debris-covered ice cones described above would seem, as Mr. McAllister suggests, to have post-dated the fall of ash. The cracks in the ash layer are very similar to those which form when any fairly thick layer of predominantly fine covering material subsides by differential melting of the underlying ice or firn. The association of the craters with the cones in all twenty cases examined suggests that this association is no mere coincidence but rather that the two features are associated by cause and effect. If we therefore assume that the craters containing the ash formed first, then the cones fall into the general category of such features now well described and well understood. On this interpretation the cones result from the retarded ablation of ice surrounding the ash-filled pockets, retarded by the mantle of extra debris which spreads down the sides of the ever-growing cones as the upper parts of the ash pockets find themselves unsupported by the down-melting of the enclosing ice. If this be so, the problem is to account for the ash-filled pockets. The firn or ice surface may have been previously pitted by the down-melting of sporadic patches of dust dark enough to absorb radiation readily, but not thick enough to insulate the underlying ice. Given such pitting I do not think it impossible for drifting ash to fill or partly fill the little pits to a greater depth than that of the ash covering the general surface of the surrounding firn or ice, much as occurs when snow drifts into little hollows. Only in relatively still air would one expect the thickness of the ash to be more or less uniform, over a relatively restricted area, irrespective of surface irregularities. But I do not think it likely that such deep and closely spaced pitting would be a natural condition of a glacier surface. Lesser irregularities there may have been at the time of the eruption, and hot ash falling in the hollows may have melted its way downwards, provided the melt water could get away, and encouraged further hot ash to drift into and further deepen the hollows. The deep cylindrical pits may represent deeper penetrations in the centres of larger, less regularly shaped hollows which had melted away by the time the observations were made in 1948 . But this is mere speculation prompted by this most intriguing problem that Mr. McAllister has posed. 